\title{
Can Management Ethics Be Taught Ethically? A Levinasian Exploration
}

\author{
Edward Trezise and Gert Biesta
}

\begin{abstract}
'My task does not consist in constructing ethics: I only try to find its meaning.' Emmanuel Levinas ${ }^{1}$ 'We name this calling into question of my spontaneity by the presence of the Other ethics.' Emmanuel Levinas ${ }^{2}$
\end{abstract}

\begin{abstract}
Courses in business ethics ${ }^{3}$ are part of most Higher Education programmes in Management and Business Studies. Such courses are commonly aimed at providing students with knowledge about ethics, usually in the form of a set of ethical and meta-ethical theories which are presented as 'tools' for ethical decision making. This reveals an approach to the teaching of management and business ethics which is based upon a cognitive view of moral education - one which sees ethical knowledge as at least a necessary condition for moral action - and in which it is assumed that ethical practice in management and business follows from the application of ethical knowledge. In this paper we ask whether the teaching of management and business ethics can be done differently and, more importantly, whether it can be done in an ethical manner, one which focuses on possibilities for being ethical rather than knowing ethics. Our explorations are informed by the work of Emmanuel Levinas and centre on the idea that responsibility is the first reality of the (ethical) self. Through a discussion of the notions of 'the face' and 'the third part' (le tiers) we explore how ethical subjectivity might be possible. We then ask what it might mean to organise a curriculum for management and business ethics around the 'experience' of responsibility-for-the-Other.
\end{abstract}

\section{Teaching Business and Management Ethics: An Overview}

According to DeGeorge, ${ }^{4}$ business ethics as an academic field came to the fore 'from the marriage between philosophical ethics and management education'. We might ask whether the conjunction of ethics, management and education was ever anything other than a marriage of convenience or, to carry the analogy further, simply an arranged marriage. A review of the business ethics literature reveals that there is a wide array of views about its nature and purpose ${ }^{5}$ and that no single conception is generally accepted. ${ }^{6}$ According to Johnson and Smith there is disagreement regarding four main issues: ${ }^{7}$

${ }^{1}$ Levinas, E Ethics and infinity. Conversations with Philip Nemo Pittsburgh: Dusquene University Press 1985 p 90

${ }^{2}$ Levinas, E Totality and Infinity (tr Alphonso Lingis) Pittsburgh: Duquesne University Press 1969

${ }^{3}$ Business ethics is the more common name for our topic. To some extent business ethics and management ethics are synonymous, and within the paper we often use the terms interchangeably. However, from a Levianasian perspective management ethics is probably the most pertinent term as it is managers who have responsibility and not businesses as corporations. Thus it would become relevant to distinguish between the two classifications when discussing corporate ethics, e.g. Corporate Social Responsibility (CSR) as it appears that this not possible from the perspective of Emmanuel Levinas - only managerial ethics remains.

${ }^{4}$ See De George in Freeman, Edward, R, Business Ethics: The State of the Art London, Oxford University Press Sage $1991 \mathrm{p} 42$

5 See, eg Drucker P 'What is Business Ethics?' Public Interest 63 (1981) pp 18-36; Lewis P 'Defining 'Business Ethics': Like Nailing Jello to a Wall' Journal of Business Ethics 41985 pp377-383; De George R 'The Status of Business Ethics: Past Present and Future' Journal of Business Ethics 6 (1987) pp 201-211; Bowie N 'Business Ethics as a Discipline: The Search for Legitimacy' in R.E Freeman (ed) Business Ethics the State of the Art Oxford University Press 1991; Enderle G What is Business Ethics?' in TW Dunfee and Y Nagayasu (eds) Business Ethics: Japan and the Global Economy Kluwer, Dordrecht 1993; Trezise, E.K 'Practical Reflections on Teaching Business Ethics to Undergraduates' in Business Ethics: A European Review Vol. 3 No3 1994 pp 180-185

${ }^{6}$ See Kaler, J 'Positioning Business Ethics in Relation to Management and Political Philosophy' Journal of Business Ethics 24: 2000 p 257

${ }^{7}$ See Johnson P \& Smith K ‘Constituting Business Ethics: A Metatheoretical Exploration' Reason in Practice The Journal of Philosophy of Management $\mathrm{Vol} 2$ no 2 (2002) p 22 
1 parameters of what constitutes business ethics;

2 the legitimate objectives of business ethics;

3 the role of the business ethicist (manager and or teacher)

4 the relevance of the differing theoretical and methodological approaches.

Macfarlane and Ottewill ${ }^{8}$ (see table below) distinguish between two contrasting approaches to business ethics: the Managerial Model and the Critical Model - each with different theoretical and practical applications - which are a 'manifestation of (the) wider debate regarding the purpose of a business and management education'. Managerial ethics is about decision making and ethics of knowledge. The Critical model is about political, social and economic theory and also ultimately about knowledge of ethics. In both management ethics and management education these 'foundations' are under attack from postmodernists in both moral and managerial education.

\begin{tabular}{|l|l|l|}
\hline & Managerial Model & Critical Model \\
\hline Theoretical foundations & Ethical theory & Economic, political and social theory \\
\hline Practical applications & $\begin{array}{l}\text { Whistleblowing } \\
\text { Bribery } \\
\text { Marketing }\end{array}$ & $\begin{array}{l}\text { Globalisation } \\
\text { Fair-trade of Free Trade } \\
\text { Meaningful work }\end{array}$ \\
\hline
\end{tabular}

Alternative curriculum models applied to business ethics (adapted from Macfarlane and Otterwill)

This model is typical of the dichotomies between different views of management ethics that is developed below.

As a subset of ethics in general, business ethics is a normative endeavour that has to do with how managers and other employees ought to act in certain situations, a sort of ' $21^{\text {st }}$ century ethical tool kit'. ${ }^{10}$ None of these 'tools' satisfactorily resolve the ethical dilemmas inherent in the system. 'The system' is capitalism or the free market, which raises the question how we should understand the role and position of business ethics within that system and within society at large. Should business ethics question the justice of the business system, as Hoffman and Frederick ${ }^{11}$ suggest it should? Or even more radically, following Lippke ${ }^{12}$ should we 'confront the structure of capitalism from an egalitarian perspective.'

Another way of understanding the divisions with the field follows from Freeman and Philips ${ }^{13}$ suggestion that business ethics developed along two lines of thought. Firstly - 'business and society' or 'social issues in management' attempts to situate business conceived primarily as an economic activity into a larger social context. This form of business ethics is most commonly found in business schools and relies on a social science methodology. Secondly - 'business ethics' stems from philosophers working in the analytical tradition, using mainly Kantian (and we would add Utilitarian and sometimes Virtue) theories. Hence, business ethics becomes no 'different to medical ethics' where these theories are 'applied (our emphasis - we shall have more to say on the distinction between applied and implied ethics below) to the context of business'. ${ }^{14}$

\footnotetext{
${ }^{8}$ See MacFarlane B and Otterwill R Effective learning and teaching in business and management London, KoganPage 2001 p 112

${ }^{9}$ Macfarlane and Otterwill op cit 2001, p 112

${ }^{10}$ See Weston A A $21^{\text {st }}$ Century Ethical Toolbox Oxford University Press 2001

${ }^{11}$ See Hoffman and Frederick, (1995) Business Ethics: Readings and cases in corporate morality New York, McGraw-Hill. Cited in MacFarland and Otterwill (2001) p112

${ }^{12}$ See Lippke R Radical Business Ethics. Lanham, MD: Rowman and Littlefield (1995). Cited in MacFarlane B and Otterwill R Effective learning and teaching in business and management London, Kogan-Page $2001 \mathrm{p} 113$

${ }^{13}$ See Freeman R Edward and Philips Robert A 'Business ethics: pragmatism and postmodernism' in $A$ Companion to Business Ethics Blackwell 1999

${ }^{14}$ See Freeman R Edward and Philips Robert A 'Business ethics: pragmatism and postmodernism' in $A$ Companion to Business Ethics Blackwell 1999 p 128
} 
As a branch of management education the teaching of business ethics may be viewed from two different perspectives. Thomas and Athony suggest a distinction between 'management education,' which is concerned with the purely socio-economic model of management, and 'management education,' which is interested in the process of human development. ${ }^{15}$ Following this distinction we can suggest that a further division is possible, viz, that of business ethics as an academic subject and as a vocational subject. This is part of what Bowie ${ }^{16}$ calls the 'search for legitimacy' within business ethics. As an academic subject management ethics is founded on a liberal arts philosophy and offers an 'education designed to give you access to the entire world of human knowledge and some idea of possibilities of human achievement'. ${ }^{17}$ The second branch is concerned with management decision making from an ethical standpoint, what Robin Snell ${ }^{18}$ terms 'managing ethically.' Hence, what we have is a distinction between business ethics as a theoretical formulation (academic) and as an actual operation (vocational) ${ }^{19}$ and the realisation that the 'ethical evaluation of the system (capitalism) is distinguishable from ethics in the system'. ${ }^{20}$

From an educational point of view, then one of the key-questions is how these discussions translate into approaches to the teaching of business ethics and management education more generally. Macfarlane and Otterwill ${ }^{21}$ suggest the following learning outcomes for business ethics:

\begin{tabular}{|l|l|}
\hline Cognitive & $\begin{array}{l}1 \text { Evaluate the value of ethical theory in determining the propriety of the course of } \\
\text { action } \\
2 \text { Explain the regulatory environment with respect to a particular profession }\end{array}$ \\
\hline Affective & $\begin{array}{l}1 \text { Manifest a tolerance of disagreement in discussing an ethical dilemma facing a } \\
\text { business organisation } \\
2 \text { Demonstrate sensitivity to ethical issues arising within the 'public' world of } \\
\text { business. }\end{array}$ \\
\hline Adaptive & $\begin{array}{l}1 \text { Apply decision-making skills in resolving moral issues in the workplace } \\
2 \text { Use persuasion skills to convince others of the efficacy of a moral stance }\end{array}$ \\
\hline
\end{tabular}

Felton and Sims, below, propose three categories of learning outcomes for business ethics that are not dissimilar to the previous set. ${ }^{22}$

\begin{tabular}{|l|l|}
\hline $\begin{array}{l}\text { Focus on developing } \\
\text { students' theoretical } \\
\text { knowledge base }\end{array}$ & $\begin{array}{l}\text { Cognitive with the goal of developing and nurturing ethical 'knowledge' in } \\
\text { students }\end{array}$ \\
\hline $\begin{array}{l}\text { Focus on analyzing issues } \\
\text { facing managers in business } \\
\text { situations }\end{array}$ & $\begin{array}{l}\text { Addresses issues, usually problems, arising in everyday business } \\
\text { situations and encourages students to consider the ethical commitments } \\
\text { and reasoning processes that might assist in addressing troubling } \\
\text { business situations }\end{array}$ \\
\hline $\begin{array}{l}\text { Focus equally on theory and } \\
\text { practice }\end{array}$ & $\begin{array}{l}\text { Half the teaching time being focused on ethical theories and the other half } \\
\text { using concepts in addressing ethical dilemmas }\end{array}$ \\
\hline
\end{tabular}

15 Thomas A and Anthony P 'Can Management Education be Educational?' in Rethinking Management Education French R and Grey C (eds) London, Sage 1996

16 Bowie N E 'Business Ethics as a Discipline: The Search for Legitimacy' in R.E Freeman (ed) Business Ethics the State of the Art Oxford University Press 1991

${ }^{17}$ Freeman E (ed) 'Business Ethics: The State of the Art' The Ruffin Series in Business Ethics London, Oxford Univeristy Press 1991 p21

${ }^{18}$ Snell R 'Managing Ethically' in Management A Critical Text, Fulop, Liz and Linstead Stephen, (eds) London, Macmillan Business 1999

${ }^{19}$ See DeGeorge 'Will success spoil business ethics?' in (ed) Freeeman, Edward R Business Ethics: The State of the Art Oxford Univeristy Press 1991 p.42.

${ }^{20}$ ibid (italics in original) p43

${ }^{21}$ See MacFarlane B and Otterwill R Effective learning and teaching in business and management London, KoganPage 2001 p 112

22 See Felton E and Sims R 'Teaching Business Ethics: Targeted Outputs', Journal of Business Ethics 60 (2005) p 37 
These examples show a common trend in the way in which business ethics is being taught in management education programmes. The focus is on 'resolving moral issues in the workplace' and dealing with 'troubling business situations' and the main assumption is that knowledge of ethical theories will provide students with a toolkit for 'addressing ethical dilemmas' and 'determining the propriety of the course of action'. The aim, in other words, is to provide students with knowledge about ethics - usually in the form of a set of ethical and meta-ethical theories - and this knowledge is seen as a tool for ethical decision-making. The underlying approach to moral education is a cognitive one in which it is assumed that ethical knowledge is at least a necessary condition for moral education. And the underlying approach to business ethics is one in which it is assumed that ethical practice will follow from the 'right' ethical decision making.

\section{Knowing Ethics or Being Ethical?}

Whereas at one level there is nothing wrong with such an approach to the teaching of business ethics - it is perfectly conceivable that courses based on these principles may indeed have a positive impact on the ethical quality of decision-making in a business context - the approach is not without problems. In fact, we see three sets of problems, ethical, philosophical and educational, and they all have to do with the distinction between knowing ethics and being ethical. The main question here is whether the knowledge of (meta-)ethical theories, ethical principles and the technicalities of their application will actually result in ethical action. This can partly be read as a practical problem, and the answer here might well be that the teaching of ethical theory and its application can only ever be a necessary but never a sufficient condition for ethical action. But there are more fundamental questions to be asked here as well.

There is first of all a set of questions that has to do with underlying assumptions about the meaning of ethics and about what it means to be ethical. The model that is implied in the common approaches to the teaching of business ethics relies upon an understanding of ethical action as a process that follows from rational ethical decision-making by an autonomous moral subject. It therefore not only has to assume that moral subjects exist autonomously before they engage in ethical judgement and ethical action. It also has to assume that ethics has a rational basis and that ethical action follows from taking the 'right' decisions. And it has to assume that ethics, and justice more generally, can actually be achieved, which means that it is, in principle, possible to know whether we have acted in an ethical and just manner. These assumptions, which point to a very particular understanding of ethics, morality and the moral subject, are linked to wider philosophical assumptions, including the assumption that cognition comes before action, the assumption of the existence of an autonomous subject who is able to make decisions about her actions and act upon those decisions, assumptions about the rationality of human judgement and action, and assumptions about what we suggest to call the transparency of human action, i.e., the fact that it is possible to make definite judgements about the quality of particular actions.

Within the confines of this paper we do not have the space to explore these assumptions in much detail - what we mainly aim to achieve is to show that these assumptions are not selfevident and that it is possible to think differently about the meaning of ethics and about what it means to be ethical. This brief exploration does show that the idea that ethical being follows from knowing ethics rests upon a very specific set of assumptions about ethics and human action. One question we might raise in this context is whether the ethical decisions and actions that follow from the application of ethical principles are indeed ethical, or whether at the end of the day they will be self-serving. (The underlying philosophical question here is why autonomous subjects would choose to be other-regarding rather than only self-regarding. Why, in other words, would autonomous subjects choose to be ethical?) There is also the question whether the application of ethical theories will result in ethical action or whether it will actually prevent us from being ethical. There is the possibility that the assumptions that underpin a particular way of understanding and teaching business ethics will actually prevent us from understanding some issues as moral matters. And there is the more general question whether it is actually possible to act ethically in a business context without questioning the wider socio-political and economic context in which business operates. 
Finally, the distinction between knowing ethics and being ethical is also important from an educational point of view. The key question here is whether a focus on the teaching of ethical knowledge and skills will actually provide students with opportunities for being ethical or whether it would make this more difficult rather than less.

\section{Ethics Otherwise: Emmanuel Levinas}

Emmanuel Levinas has been acclaimed as 'one of the most significant ethical thinkers of the twentieth century'23 as the greatest moral philosopher of this century ${ }^{24}$ and as one whose thought 'can make us tremble'. ${ }^{25}$ Levinas studied under both Edmund Husserl and Marin Heidegger in Freiburg in 1928 and 1929 and devoted much of his early philosophical development to explicating their work and its significance to his French compatriots. He remained involved in phenomenology even as he developed a post-phenomenological ethics which establishes itself in opposition to the philosophies of his two teachers. In a sentence, Levinias's criticism of Husserl and Heidegger is identical: both thinkers subsume the Other under the authority of the same, which is understood as consciousness in Husserl and Being in Heidegger. The process was a slow one and began with Theory of Intuition of the Phenomenology of Husserl in 1930 and culminated in Totality and Infinity in 1961.

Central to Levinas's thought is a critical reading of Western philosophy in general. He writes:

Western philosophy coincides with the unveiling of the other in which the Other, by manifesting itself as a being loses its alterity. Philosophy is inflicted, from its childhood, with an insurmountable allergy: a horror of the Other which remains Other. It is for this reason that philosophy is essentially the philosophy of Being; the comprehension of Being is its final word and the fundamental structure of man. ${ }^{26}$

Levinas's point here is, in a sense, amazingly simple, but has major consequences. The point is that philosophy has been characterised by its failure to think of the Other as Other. In an oft quoted passage from Totality and Infinity27 Levinas expresses the issue as follows:

A calling into question (mise en question) of the Same - which cannot occur (se faire) within the egoistic spontaneity of the Same - is brought about (se fait) by the Other (l'Autre). We name this calling into question of my spontaneity by the presence of the Other (l'Autre) ethics. The strangeness of the Other, his irreducibility to the I $(M o i)$, to my thoughts and my possessions, is precisely accomplished (s'accomplit) as a calling into question of my spontaneity, as ethics. Metaphysics, transcendence, the welcoming of the Other by the Same, of the Other by Me, is concretely produced (se produit) as the calling into question of the Same by the Other, that is, as the ethics that accomplishes (accomplit) the critical essence of knowledge. ${ }^{28}$

As Davis suggests, the whole of the philosophy of Totality and Infinity is contained in embryo in this passage'. ${ }^{29}$

Another philosopher that Levinas reinterprets is Descartes, particularly the 3rd Meditation. In Meditations (1641) the subject is founded in infinity. ${ }^{30}$ The Cartesian subject seizes itself as a subject by reference to the none-self. For Levinas the significance of the Cartesian discovery lies

\footnotetext{
${ }^{23}$ According to Kearney R \& Rainwater M The Continental Philosophy Reader Routledge 1996 p112

${ }^{24}$ See Bauman Z Intimations of Postmodernity London, Routledge $1992 \mathrm{p} 41$

${ }^{25}$ See also Derrida J 'Violence and Metaphysics' in Writing and Difference Translated by Alan Bass Chicaco, 111, London, Routledge 1998 and Kegan Paul p.82

${ }^{26}$ Levinas, E 'The Trace of the Other' translated by Alfonso Lingis, in: (ed) Mark C Taylor Deconstruction in Context: Literature and Philosophy Chicago, University of Chicago Press 1986 p 346

${ }^{27}$ Levinas op cit 1961

${ }^{28}$ Levinas op cit 1961 p 43

29 Davis C Levinas: An Introduction Cambridge Polity Press 1996 p36

${ }^{30}$ The arguments are very difficult here, but one of the central aims of Totality and Infinity is 'to present itself as a defence of subjectivity' and this subjectivity will be 'founded in the idea of infinity', 'not at the level of it purely egoist prostestation'...'nor in its anguish before death' (Totality and Infinity 26) See Davis (op cit 1996) pp 3840 for a close analysis of this idea.
} 
in the encounter with the infinite as something beyond knowledge and utterly resistant to the solipsism of the transcendental ego ${ }^{31}$ 'Descartes, better than an idealist or a realist, discovers a relation with a total alterity irreducible to interiority, Which nevertheless does not do violence to interiority - a receptivity without passivity, a relation between freedoms'. ${ }^{32}$ Leora Batnitzky ${ }^{33}$ expresses a great deal of this idea in the following passage:

It is the self's sense of itself as a separable, independent self that is the core philosophical argument of Totality and Infinity. Against Heidegger Levinas maintains that there is a separable subject whose identity who cannot be reduced to any web of relations. From Levinas's point of View Heidegger's 'mine' reduces the self to nothing, while Husserl's 'mine'overly cognizes the identity of the ego. Levinas's attempt to make ethics first philosophy is captured in his 'mine,' which contra Husserl is not a cognitive matter and contra Heidegger transcends social and historical relations. Levinas's 'mine' concerns my unique responsibility for the other person. This responsibility is 'mine' alone and I am uniquely defined by it. I do not possess this responsibility; rather this responsibility is me. $^{34}$

The next step in Levinas's argument is that the Same and other are described as originally and fundamentally ethical in nature.

From the viewpoint of the Anglo-American analytical tradition, Levinas works seemingly meets none of the conditions by which an ethical philosophy or meta-ethical philosophy might be recognised. Most importantly he does not comment on the classic debates between the conseqentialists. ${ }^{35} \mathrm{He}$ does not get involved in the Kantian 'What ought I to do' ${ }^{36}$ nor does he provide foundations or rules for morality. In an interview with Philippe Nemo, he states, 'My task does not consist in constructing ethics; I only try to find its meaning. ${ }^{37}$ Perhaps, crucially for our purposes he adds: 'One can without doubt construct an ethics in function of what I have just said, but that is not my own theme' ${ }^{38}$ Like a radical non-cognitivist, he implies that such questions are beyond the scope of philosophical enquiry. ${ }^{39}$ But in what sense, then, is Levinas a philosopher of ethics? Obviously not in the traditional sense of someone who offers us a theory of ethics or an ethical theory. Levinas helps us to see the meaning of ethics - and more specifically the meaning of being ethical - differently, and suggests a strong link between being and ethics, and more specifically my singular being and ethics. In this respect we might say that Levinas does not offer us a philosophy of ethics, but rather an ethics of subjectivity (for this notion see Biesta in press). This is for example expressed in the idea of 'the face'.

The face in which the Other - the absolutely other - presents himself does not negate the Same, does not do violence to it as do opinion or Authority or the thaumaturgic ${ }^{40}$ supernatural. It remains commensurate with him who welcomes; it remains terrestrial. This presentation is pre-eminently non-violence, for instead of offending my freedom it calls it to responsibility and founds it. As nonviolence it nonetheless maintains the plurality of the Same and Other. It is peace. ${ }^{41}$

\footnotetext{
${ }^{31}$ Davis C Levinas: An Introduction Cambridge, Polity Press 1996 p39

${ }^{32}$ Levinas op cit 1961 p 211

${ }^{33}$ Batnitzky L 'Encountering the Modern Subject in Levinas' in Encounters with Levinas Thomas Trezise (ed) Yale French Studies 104 (2003) pp 6-21

${ }^{34}$ Batnitzky L op cit $\mathrm{p} 13$ emphasis in original

${ }^{35}$ For the contrast between teleological and deontological theories, see Williams (1993 p 16). The former are characterised as 'theories that take as primary the idea of producing the best possible state of affairs, whereas the latter 'take as basic a notion of obligation and duty.'

${ }^{36}$ But see Chalier, C What Ought I to do? Morality in Kant and Levinas Cornell University Press 2002

${ }^{37}$ See Levinas Ethics and infinity. Conversations with Philip Nemo Pittsburgh, Dusquene University Press 1985 p 90

38 ibid Just how possible/desirable this may be will be taken up in a following section. It mainly considers the distinction between applied and implied ethics.

${ }^{39}$ See Wittgenstein L 'A Lecture on Ethics,' Philosophical Review, January 1965 pp 3-12. 'This whole tendency and I believe the tendency of all men who ever tried to write or talk ethics or religion was to run against the boundaries of language. This running against the walls of our cage is perfectly, absolutely hopeless. Ethics so far as it springs from the desire to say something about the ultimate meaning of life, the absolute good, the absolutely valuable can be no science. What is says does not add to our knowledge in any sense.' And 'I can only describe my feeling by the metaphor, that if a man could write a book on Ethics which really was a book on Ethics, this book would, with an explosion, destroy all the other books in the world.' (ibid p 7)

${ }^{40}$ Thaumaturge, a performer of miracles, miracle working: the Colins English Dictionary

${ }^{41}$ Levinas op cit 1961 p 203
} 
The other puts me into question by revealing to me that my powers and freedom are limited. However, this force does not annihilate the self, on the contrary, it is the condition of separateness. It instigates dialogue, teaching and hence reason, society and ethics. ${ }^{42}$ It also gives a proper foundation to freedom. The decoupling of responsibility from reciprocity, distinguishes Levinas ethics from virtually all others. This ethics refuses the Kantian move of establishing reason as the foundation of ethics, since if reason is the consensus between all rational subjects, there is not dialogue in it (though there may be dialogue about it). It allows for no encounter with the Other and represents only the seamless monologue of the Same. ${ }^{43}$

Levinas's ethics then provides one of the best avenues to think through the consequences of the postmodern situation - that of an ethics without foundation or universitality . Zygmunt Bauman reflects this condition well:

That the post-modern mind is aware of is that there are problems inhuman and social life with no good solutions, twisted trajectories that cannot be straightened up, ambivalences that are more than linguistic blunders waiting to be corrected, doubts which cannot be legislated out of existence, moral agonies which no reason- dictated recipes can soothe, let alone cure. The postmodern mind does not expect any more to find all-embracing, total and ultimate formula of life without ambiguity, risk, danger and error, and is deeply suspicious of any voice that Promises otherwise. (. . .) The postmodern mind is reconciled to the idea that the messiness of the human predicament is here to stay. ${ }^{44}$

This is morality as aporetic, never resolved and without recourse to the 'safe' rules or principles which help simplify difficult choices. Levinas offers us an account of the subject as ethical in very foundations, involved in ethical relations whether it likes it or not. Of course, I can behave unethically, ${ }^{45}$ indeed any compulsion within the ethical obligation would deprive it of its morality. 'For Levinas the ethical is the condition of my existence whatever the worth or worthlessness of my actions. ${ }^{36}$

\section{Making a Difference in (the Teaching of) Business Ethics}

That the 'postmodern mind is reconciled to the idea of messiness...' as suggested above effects both ethical theories and management theories and of course they converge in management ethics in which the three sets of problems outlined in section Two (ethical, philosophical and educational). How does Levinas differ from the key-assumptions that we found in the traditional approach and what does it mean to make the distinction between knowing ethics and being ethical in teaching management ethics?

The first question is 'Can we teach ethics and if so how should we do it?' Do we want our students to know moral theory or to act morally? For Levinas ethics is not cognitive content, 'the outcome of some practical or moral reasoning process as proposed, for example by Kant'. ${ }^{47}$ As Caputo ${ }^{48}$ suggests moral reasoning comes too late - 'like a crowd after an accident that now argues about what went wrong, who is to blame, what ought we have done - so too with ethical theorists/theory' ${ }^{49}$ For Levinas the claims of traditional ethics that we can know the right thing to do is to bring the other into the same, to take control over him/her. My consciousness 'absorbs' the Other into a category or theme (the face) to become and example of 'mine'. Within this category that my ego controls, we can reason about 'rights, obligations,

\footnotetext{
${ }^{42}$ Levinas Totality and Infinity 1969 pp203-4

43 Levinas op cit 1961 pp 207-8, 228-9

${ }^{44}$ Bauman Z Postmodern ethics Oxford, Blackwell 1993 p245

${ }^{45}$ Levinas op cit 1961 pp172-3

46 Davis C Levinas: An Introduction Cambridge, Polity Press 1996 p54

${ }^{47}$ See Introna, Lucas Justice and Responsibility On (not) teaching computer and information ethics working paper http://www.lums.co.uk/publications 2003 accessed 31/07/06

${ }^{48}$ Caputo Against Ethics Indianapolis, Indiana University Press 1993 and Caputo More Radical Hermeneutics: On not knowing who we are Indianapolis, Indiana University Press 2000

49 This quote appears in Lucas Introna's paper (2003,p3) the first author is indebted to Dr Introna's paper for the general arguments of this section.
} 
laws and principles, and yet ethics may never happen'. ${ }^{50}$ Real faces starve, die, are humiliated, ignored. As we present our arguments and counter arguments we might feel justified that we have offered reasons for our action; we did the right thing after all. Or did we?

Levinas allows us to question the received wisdom of business ethics teaching and rather than leaving one with an vacuum in which both tutor and student feel powerless or threatened he offers an ethics that is not a branch of philosophy but 'First Philosophy'; one in which the autonomous subject is not ethical through reasoning, but true uniqueness, true autonomy is the fact that no one can answer for me. Morality is not a moral choice by a free self certain ego - it is in the encounter with the infinitely other that I become questioned and accept my responsibility. My subjectivity always refers already to the Other as its source, its moral source. As Cohen argues:

Moral forces cannot be reduced to cognitive cogency, to acts of consciousness or will. On can always refuse its claim....and the capacity to rationalize such a refusal is certainly without limit. Ethical necessity lies in a different sort of refusal, a refusal of concepts. It lies in the pre-thematic demands that are necessarily lost in the elaboration of themes. Ethical necessity lies in the social obligation prior to thematic thought, in the disturbance suffered by thematic thought...This is not because ethics makes some truths better or worse, but because it dismupts the entire project of knowing (author's emphasis) with a higher call, a more severe 'condition': responsibility. ${ }^{51}$

This 'disruption' to quote Cohen again 'opens up the dimension of goodness'. ${ }^{52} \mathrm{He}$ continues:

Goodness leads to the requirement to be just, hence the requirement for philosophy. (...)Levinas not only reorients the relation of ethics to epistemology, and in the process provides an account of the origin of philosophy, but even more importantly he justifies philosophy. (emphasis in original).

In 'justifying philosophy' Levinas moves beyond rational ethics into responsible ethics based on relation or inter-subjective ethics and illustrates (1) that ethics is not only about individual ethics, but is about responsibility for the Other(s) before one's self, that is 'Justice'; and (2) that the possibility that teaching business ethics can move from the applied ethics of the traditional theories discussed in part one above to an implied ethics that is Levinasian in nature.

In (1) he illustrates that subjective ethics is at the same time (simultaneously in the face) and a social justice of the third party (le tiers). That is as the face of the other gives raise to subjective ethics, responsibility for the Other is contain therein, at the same time...

The third party looks at me in the eyes of the Other - language is justice. (...) The epiphany of the face qua face opens humanity. The face in its nakedness as a face presents to me the destitution of the poor one and stranger, but this poverty and exile which appeal to my powers, address me, do not deliver themselves over to these powers as givens, remains the expression of the face. The poor one, the stranger, presents himself as an equal. His equality within this essential poverty consists in referring to the third party, thus present at the encounter, who in the midst of his destitution the Other already serves. ${ }^{53}$

Hence the idea that we are self-interested and obligated only to ourselves is shown to be mistaken...Levinas answers the question why be good? This is a crucial question for business ethics in society as expressed in section one; -is it possible to teach ethics without considering the wider socio-political and economic background in which business operates? .It would appear not as from a Levinasian viewpoint the dichotomy (see table above on Managerial and Critical approaches) between theory and practice is avoided as ethics precedes it. This suggests that ethics cannot be taught, but only encouraged via an implied ethics.

\footnotetext{
${ }^{50}$ See Introna, Lucas Justice and Responsibility On (not) teaching computer and information ethics working paper p 3 http://www.lums.co.uk/publications 2003 accessed 31.07.06

${ }^{11}$ Cohen R (ed) Face to Face with Levinas, New York, State University of New York Press 1986 p 5

${ }^{52}$ Cohen, R The Theory of Intuition in Husserl's Phenomenology $2^{\text {nd }}$ Ed Illinois, Evanston, Northwestern University Press 1998

${ }_{53}^{53}$ Levinas op cit 1961 pp 213 and 234
} 
In (2) Levinas suggests that ethics is the foundation for philosophy and for a caring justice for all Others both near and far. Both these issues have potentially profound impact on the teaching of management ethics. It is to this impact that we now turn.

\section{A Levinasian Syllabus - How (Not) to Teach Management Ethics?}

So far then we have argued that there are two sides of management ethics education, the prevailing view in which ethical theories are primarily concerned to enhance management effectiveness and efficiency or the more critical approach that questions the role and importance of business (ethics) within society as a whole. Grey et al ${ }^{54}$ suggest that a critical approach should start with the student's own lived experiences not to make the transmission of knowledge a vehicle for more effectiveness in management but to 'provide a basis for a critical reflection on experience as a means of subverting such knowledge'.

This is fine in terms of beginning with the 'students' own experience, but difficult to justify in simply subverting knowledge or even becoming aware of the many views of knowledge and developing a critical awareness of them. But the danger here is that in exposing the students to these modes of critique one may affect 'their cultural displacement, alienation and disillusionment'. ${ }^{55}$ They suffer what Fenwick calls a 'classic extistential split' between the 'I' that is the critical thinker an the 'I' that is the future manager. 'Those taking up the critical subject position often end up asking, But how, can I possibly work in (contemporary organisations)?'56 This, however, is the I of ego and it is not Levinas's view. He is more concerned with the Subject (Subjectivity) and his ethics does not take place at the level of consciousness or reflection, rather it takes place at the level of sensibility or pre-conscious sentience. The Levinasian ethical subject is a sentient self (un soi sentant) before a being a thinking ego (un moi pansant). ${ }^{57}$ It is here that we begin to discover implied ethics.

Shifting the focus from education as a scene where one ought to apply this or that principle, to a scene where the conditions or conditions or contingencies of ethicality may be found, means no longer simply thinking about education in relation to ethics; rather, it means thinking about ethics through education, this means exploring the day-to-day details of pedagogical encounters to see what they might offer in putting forth an understanding of education as a site of implied ethics, rather than applied ethics. To explore this idea of implied ethics more fully necessitates reading teaching-learning encounters for the way they promote conditions for ethicality as they promote conditions for being, both of which involve relationships between Self and Other. ${ }^{58}$

How might one construct a syllabus that teaching and learning is ethical but not about knowledge transfer, one that is about the emergence of the 'ethical' in the very encounter with the other and Other? It is not possible to begin with Levinas. We must begin in such a way as to unlearn much of what is taken for granted in a business school - the Enlightenment project of 'fitting the corporeal (corporate) 'man' into the economic and political Order's9 needs to be challenged. Here are some aspects of a Levinasian approach to Management Ethics developed by the first author.

\section{Teaching and Learning}

A 'Mind-Map' (see below) developed to aid students (and the tutor!) into thinking about business ethics from a Levinasian perspective - this is the most recent development (2 years) and was introduced to offer the students' a 'picture of what may emerge in the course as the

${ }^{54}$ Grey, Knights and Willmot Rethinking Management Education 1996

${ }^{55}$ Fenwick 'Ethical Dilemmas of Critical Management Education: Within Classrooms and Beyond' Management Learning, Vol.36 (1) (2005) p34

${ }^{56}$ ibid p 35 (emphasis in original)

${ }^{57}$ See Critchley Ethics, Politics, Subjectivity London, Verso 1999 p 194

${ }^{58}$ Todd 'Bringing more than I can contain: ethics, curriculum an pedagogical demand for altered egos' Journal of Curriculum Studies Vol. 33 No 4 (2001) pp 431-450

${ }^{59}$ Michleson 'Usual suspects: experience, reflection and the (en)gendering of knowledge' International Journal of Lifelong Education Vol. 15 no 6 (Nov-Dec) (1996) p 441 
transition from knowledge learning to self development is not clear to many students. The topic for traditional teaching and learning are outlined on the bottom two rows entitled Lecture/seminar; these support the student in developing subject knowledge (M.E) whilst encouraging meta-ethical thinking. The idea is to make the teaching, learning and assessment as transparent as possible. This hopefully, develops trust between all concerned as ethics emerges in the 'relation' of one to the other. The learning is set to be non-linear, that is students are encouraged to 'move about' the map in away that suits them. This also allows them to develop at their own pace in the order that fits with their current knowledge and interest(s) (or lack of them).

In order to envelop and develop the two areas of ethical knowledge and the students' experience we need to have a vehicle which allows the student and tutor to 'track' their progress (processes). The model below illustrates how the student is encouraged to reflect on the subject matter and then in reflexion, consider how s/he is affected by this - eg she might know that it is right to buy Fair-trade products but reasons that she cannot afford it as she is a 'poor' student.

\section{Subject-knowledge (Management model)}

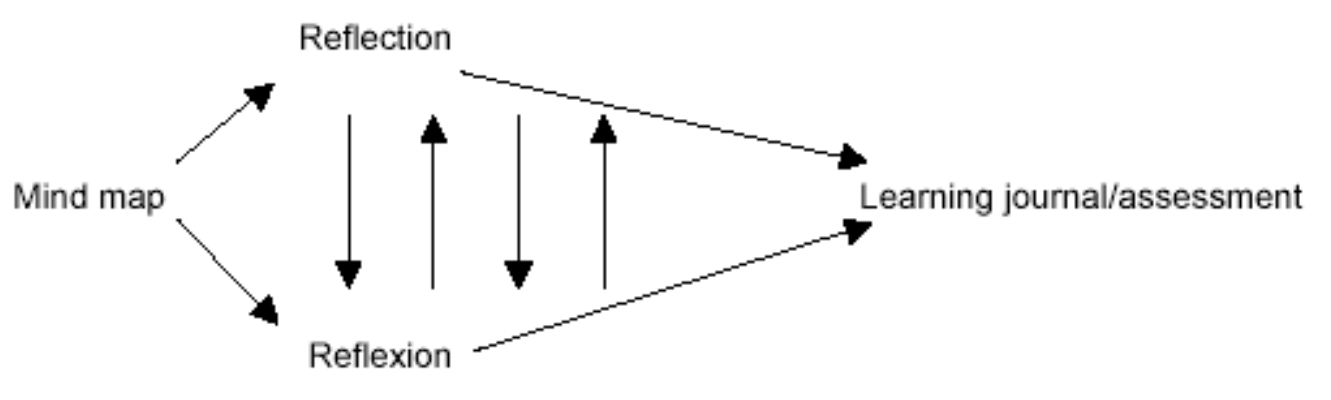

Self-knowledge (Critical model)

Reflection $=$ thinking about the subject matter i.e. Whistle-blowing

Reflexion $=$ how does the subject impact on me? What would/could I do?

Teaching is difficult because the students' are not accustomed to being asked their views and thinking critically. Whilst many expect to be told what they need to know and how to meet learning outcomes - 'tell me what you know, that I need to know to pass the module' - many respond to the challenge ${ }^{60}$ of taking responsibility for their own learning, coming to realise that to manage is to do just that. Others feel threatened and exposed and voice anger, guilt, frustration, puzzlement and fear. Most realise at some point that they are only being exposed to the 'post-modern' situation expressed by Bauman of aporia, ambiguity and change.

\section{Assessment}

Reflections and reflexions are kept in a Learning Journal on a weekly basis and entries are made both from the perspective of the lecture/seminar topic and the learning journal questions/tasks in each. Entries are made under the following suggested headings:

1 The module

2 Awareness of ethical issues

3 Development

4 External events

5 Self- knowledge

${ }^{60}$ See also Biesta G Beyond learning. Democratic education for a human future Boulder Co, Paradigm Publishers 2006 
Students are asked to comment, question and reflect on each of the above, but not in the same amount of depth or breadth each week as each week will be different for each student.

A Critical Review is written at the end of the module and is the syntheses of all the processes the student has experience throughout the module. The same headings as for the learning journal are used but students are free to write under headings they have devised, in consultation with the tutor. It is 2000 words long. This can be a very interesting piece of work or it can be a 'tool for complaint'.

Marking is based on the course work and the student hands in both the Learning Journal and the Critical Review. In order to accommodate the question 'how does one objectively mark a subjective piece of work' students are encouraged argue for a mark band by illustrating what they have achieved in the Critical Review (over the course of the module) and how this is illustrated in the Learning Journal.

\section{Example From the Syllabus}

In the second week the students are (re) introduced to Pinocchio, in the form of the Disney film and the actual story - it is suggested that many people are just like puppets who need to have their string pulled in order to act; (think of Kohlberg's cognitive moral reasoning stages) The question set in the Mind-map, Learning Journal (LJ) week 2, entry 3 is, 'Are we fully human in a moral sense'? This sets the scene for the implication that it is ethics that make us human ('what it means to be a human being is to be open to the radically noncomprehensibility of the Other' ${ }^{\prime} 1$ and that (management) ethics is the vehicle in which we may travel on this journey - we never arrive (life long learning) but we may become more human along the way.

Pinocchio is just like us, he has been granted life but is not yet fully human; in order to become a 'real boy' he must be 'Brave, truthful and unselfish' and 'learn to choose between right and wrong' - 'How will I know' he asks, 'your conscience will tell you' says the Blue Fairy...in short we are responsible for our actions and we cannot substitute any one to take our place. This story sets the scene for the module as we move from knowledge and rationality to responsibility and relation, and is repeated at the 'end' of the module (entry L1, in week 12)... by then many students will be able to reflect that they have moved from the knowledge of ethics to being ethical - they have become more human.

\section{Conclusions}

In this paper we have explored what it might mean to teach management ethics ethically. We have argued, with Levinas, that ethics does not consist of the application of ethical knowledge, but that we rather should look for the opportunities for 'being ethical' in human and educational encounters and experiences. This requires a different kind of curriculum and a different approach to teaching and learning, and we have outlined briefly some of the starting points for such an approach. There are, of course, many questions left and there is, of course, more work to do in trying to understand the possibilities for being ethical and ethical being in the teaching of business ethics. This paper has only been a first step in our thinking about these issues. We conclude with nine questions or 'reminders' that point towards the further development of an ethical approach to business ethics that listens to and tries to respond responsively to Levinas. ${ }^{62}$

\footnotetext{
${ }^{61}$ See Critchley Ethics, Politics, Subjectivity London, Verso p 751999 and Levinas op cit 1961 p 90

${ }^{62}$ See also Biesta G 'Learning from Levinas: A response' in Studies in Philosophy and Education_22(1) (2003) pp 61-68 in press
} 


\section{Edward Trezise and Gert Biesta}

What impact does listening and responding to Levinas might have on teaching business ethics?

1 Recognising difference: each student is unique and, each encounter is unique as well

2 Relationships: foster trust between staff and student and student with students

3 Emergence: education becomes not just (transferable) skills, but a 'vigilance' towards the other.

4 Responsibility: each student is confronted with his/her responsibility for their learning and the learning of Others

5 Others: students begin to realise that the interests of others may be in their own interest too.

6 Being: we become aware that being good is different from doing the right thing and distinguish between having and being

7 Ethical Action - students gain a sense that their actions can make a difference, even if it means simply buying Fair-Trade coffee, for example. Ethics is more about changing one's self than changing the world.

$8 \quad$ Life and Learning are not separate entities - their experiences count.

9 Students respond to situations and others rather than that reacting.

\section{Edward Trezise}

Edward Kingsley Trezise is Senior Lecturer in Ethics and Philosophy for Management at The Business School, University of Gloucestershire, where he is involved in bringing philosophy into the management curriculum over each year of a developing Business Management Degree. $\mathrm{He}$ is also a Doctoral candidate at The Stirling Institute of Education, supervised by Professor Biesta.

etrezise@glos.ac.uk

\section{Gert Biesta}

Gert Biesta is Professor of Education and Director of Postgraduate Research, at The Stirling Institute of Education, University of Stirling, Scotland, UK. His many book publications include Beyond Learning: Democratic education for a human future (2006) and a co-authored work Education, Democracy and the Moral Life (2008). He has published numerous articles on various educational topics. 